\title{
PATHOGENETIC MECHANISMS AND THERAPEUTIC ASPECTS OF OMEGA-3 POLYUNSATURATED FATTY ACIDS IN DIABETES MELLITUS (literature review and own data) ${ }^{*}$
}

\author{
V. Serhiyenko, S. Azhmi, L. Serhiyenko, A. Serhiyenko \\ Danylo Halytsky Lviv National Medical University; Lviv, Ukraine \\ serhiyenkoa@gmail.com
}

Diabetes mellitus (DM) is a global epidemic affecting at least $8.3 \%$ of the population and 371 million people worldwide with a significant proportion (50\%) remaining undiagnosed. It is estimated that almost one of six people are currently at risk of developing diabetes-related complications $[1,2]$. The majority of patients with long-term course of DM [mainly type 2 diabetes mellitus (T2DM)] are diagnosed with coronary heart disease (CHD) due to coronary artery atherosclerosis. Often the course of CHD is complicated by combination of hypertension, specific kidney arterial involvement, eyes and lower limbs affection. Metabolic alterations in the myocardium are combined with early coronary atherosclerosis. All these changes in heart occur out of prolonged duration of DM among middle age and elderly patients [coronary vessels affection, myocardium changes, diabetic cardiovascular autonomic neuropathy
(CAN) and arterial sclerotic disease] are associated with the term «diabetic heart or diabetic cardiomyopathy». Conditionally, there are two main forms of heart disease in case of DM: diabetic cardiomyopathy (non-coronary genesis); ischemic heart disease (IHD). There is a metabolic stage (actual cardiomyopathy); metabolicischemic stage is chemic heart disease; myocardial infarction (MI); dystrophic coronary cardiosclerosis; CAN [3, 4].

Numerous studies report salutary effects of omega-3 polyunsaturated fatty acids (omega-3 PUFAs), i. e. eicosapentaenoic (EPA) and docosahexaenoic acid (DHA) on cardiovascular diseases (CVD) risk factors. These effects include lowering of serum triglyceride (TG) by reducing of hepatic TG production; lowering of blood pressure (BP) by improving of endothelial cell functution; decreasing of platelet aggregation by reducing of prothrombotic prostanoids;

* The study was conducted as part of the research work of the Department of Endocrinology of Danylo Halytsky Lviv National Medical University «Specifics of metabolic, functional, and structural disorders of the cardiovascular system and digestive organs in patients with diabetes mellitus» (State Registration Number 0111U000131).

Institution, which financed the research: Ministry of Health of Ukraine.

The authors assume responsibility for the published work.

The authors guarantee absence of competing interests and their own financial interest when carrying out the research and writing the article.

The manuscript was received by the editorial staff 29.08.2018. 
decreasing inflammation via reduction in 4-series leukotrienes (LT) production; protection from arrhythmias by modulation of electrophysiological properties of cardiac myocytes $[5,6]$.

\section{Omega-3 polyunsaturated fatty acids: a brief overview}

Several experimental studies have shown that long-chain omega-3 PUFAs inhibit the absorption of cholesterol in the intestine and its synthesis in the liver, lead to increased clearance of lipoproteins in the blood, prevent the development of insulin resistance (IR) in experimental diabetes, increase the level of glucose transporter type 4 (GLUT4) mitochondrial RNA in skeletal muscles, have a positive effect on age related decrease of blood flow in the brain and improve glucose utilization in hypertensive rats under stress; there isn't any influence on the development of hypertension and obesity.

Omega-3 PUFAs decrease level of BP, dosedependent prevent the development of DM, IR, improve the sensitivity to platelet adenosine diphosphate (ADP) and collagen, contribute to positive changes of blood coagulation; enhance endothelial cell migration and inhibits the proliferation of smooth muscle cells [7-9].

Omega- 3 and omega- 6 PUFAs are essential fatty acids, as they cannot be synthesized $d e$ novo in humans. In food sources main omega-3 PUFA are: alpha-linolenic (alpha-LLA, C18:3 omega-3), EPA (C20:5 omega 3) and DHA (C22:6 omega-3). The long-chain omega-3 fatty acids, EPA and DHA can be synthesized from alpha-ALA, they are more easily absorbed and are essential for growth support, development and brain function. The metabolism of long-chain derivates of linoleic acid and alphaALA is accompanied by a series of desaturase and elongase enzymes conversation, but the efficiency is low in humans. Consequently, omega- 6 and omega-3 fatty acids are essential nutrients. The synthesis of eicosanoids in the cyclooxygenase (COX) lipoxygenase (LOX) and cytochrome P450 epoxygenase pathways is accompanied by competitive relationship between EPA, DHA and arachidonic acid (AA), which prevents the production of thromboxane $\mathrm{A}_{2}\left(\mathrm{TXA}_{2}\right)$; and optimal synthesis substrate is omega-3 PUFAs [10-12].
There are limited data available regarding the exact amount of dietary omega-3 PUFAs consumed by the general population. It is reported that the total daily intake of dietary omega-3 PUFAs in the USA is approximately $1.6 \mathrm{~g}$. Of this alpha-LLA account for approximately $1.4 \mathrm{~g} /$ day and only 0.1-0.2 g/day comes from EPA and DHA. The conversion rate from alpha-LLA to EPA and DHA is variable (0.2-15\%). Therefore, in general, the total amount of EPA and DHA available to the body from current dietary patterns is well below the recommended amounts [11].

Treatment with omega-3 PUFAs in moderate doses can significantly reduce the risk of fatal CHD. Lower mortality rate is probably associated with their antiarrhythmic properties and reduction of atherosclerosis progression [13, 14]. The positive relationship between consumption of omega-3 PUFAs and lower rate of coronary artery diseases was demonstrated in Greenland Eskimos, which may be partly due high consumption of fish and seafood [15]. These traditional Inuit foods contain large amounts of omega-3 PUFAs from fish oil (C20-C22 omega-3) [16]. Later a negative correlation between high mortality rate due to $\mathrm{CHD}$ and consumption of fish oil was found, that allowed to suggest antiatherosclerotic and/or antithrombotic properties of omega-3 PUFAs. However, this hypothesis has been questioned since it was shown that even of high omega-3 PUFAs consumption didn't significantly affect the appearance and/or progression of atherosclerosis, or the manifestation of CHD [13, 14, 17].

In the Cardiovascular Health Study, higher levels of omega-3 PUFAs in plasma phospholipids were associated with a lower risk of fatal CHD, but not with a lower risk of non-fatal MI [13, 18, 19]. There was also no association between fish intake and risk of non-fatal CHD in the Physicians' Health Study. Thus observational studies suggest that a modest intake of fish is associated with a lower risk of fatal CHD, but not with non-fatal heart diseases [10, 13]. The GISSI-Prevenzione trial, a randomized open label study in 11.324 patients with a recent $\mathrm{MI}$, demonstrated that patients had a $15 \%$ lower combined risk of mortality, nonfatal MI and stroke upon supplementation for 3.5 years with $850 \mathrm{mg} \cdot$ day $^{-1}$ of omega-3 PUFAs. 
The relative risk of cardiovascular death was also decreased by $30 \%$ and of sudden death by $45 \%$. The DART trial 1 (the Diet and Reinfarction Trial) was carried out in 2033 men with a recent MI. Men who received advice to increase their fish intake to at least two meals per week, compared with no advice, had a $29 \%$ lower mortality rate during the 2 year follow-up [13, 20, 21]. In contrast, the second DART trial in 3114 patients with stable IHD without a MI, showed no beneficial effect of omega-3 PUFAs intake during 9 year followup. In this trial, advice to eat fatty fish did not lower mortality, and intake of fish oil supplements was associated with a higher risk of cardiac and sudden death. However, methodological problems may have affected the outcome as compliance to advice was only shown for a subsample of patients. Unfortunately, both participants and providers were not masked, which implies that the intake of fish oil may have modified the behaviour of both patients and physicians towards intake of medication or diet and lifestyle. Furthermore, recruitment for DART-2 was interrupted for 1 year because of funding problems [13, 21, 22]. The JELIS trial was performed in 18.645 men and women with hypercholesterolaemia treated with statins. Supplementation with $1.8 \mathrm{~g}$ EPA per day decreased major coronary events by $19 \%$ over 4.6 years [13, 23].

The Alpha-Omega Trial was a multi-center, double-blind, placebo-controlled trial in 4837 patients after a MI [13, 24, 25]. Patients were randomly assigned to receive four trial margarines: a margarine supplemented with $400 \mathrm{mg}$ of EPA+DHA, a margarine supplemented with $2 \mathrm{~g}$ of alpha-LLA, a margarine supplemented with both, or a placebo margarine. The primary end point was a combination of fatal and non-fatal cardiovascular events and cardiac interventions, but SCD was not specifically followed. Study size estimation was initially based on a CHD mortality of $4 \%$ per year, and the usual assumptions, but had to be adjusted because of a lower mortality observed. The authors concluded that «Low-dose supplementation with EPA-DHA or alphaALA did not significantly reduce the rate of major cardiovascular events among patients who had a MI». More recently, the authors of the Alpha-Omega Trial reported a protective effect against ventricular arrhythmia related events in the subgroup of post-MI patients with T2DM [9, 24, 25]. The only trial ambitiously using sudden cardiac death (SCD) as a primary endpoint was "OMEGA» a multicenter, doubleblind, randomized, placebo-controlled trial comparing 1 g/day EPA + DHA as an ethyl ester to an olive oil placebo for 1 year in 3851 patients shortly after a MI [26]. Study size was estimated based on previous registry data with SCD projected to occur in $1.9 \%$ in the group treated with omega-3 acid ethyl esters 90 and $3.5 \%$ in the placebo group, and alpha of $2.5 \%$ and a power of $80 \%[9,26]$. Primary analysis was by intention-to-treat, and SCD occurred in $1.5 \%$ of both verum and placebo groups, with other cardiovascular events also evenly distributed. As is, OMEGA had a statistical power of $44 \%$ to detect the assumed reduction in SCD. This power obviates any conclusion on the effect of EPA + DHA, because it remains unclear, whether the intervention tested was ineffective or the study size was too small. The authors discussed an unexpected low rate of SCD, cross-contamination by in increase in fish consumption, and improvements in drug therapy as reasons for their results. The authors concluded that "Guideline-adjusted treatment of acute MI results in a low rate of SCD and other clinical events within 1 year of follow-up, which could not be shown to be further reduced by the application of omega-3 PUFAs».

\section{Omega-3 polyunsaturated fatty acids and glucose metabolism}

EPA and DHA didn't show a significant negative effect on glucose metabolism. In particular, it was found that in 24 patients with T2DM violations of glycaemic control wasn't observed (8-week study of the effect of 900 or $1800 \mathrm{mg}$ EPA/day). Prescription to patients with T2DM and nephropathy 900 or $1800 \mathrm{mg}$ EPA/day for 3 mo hadn't any negative effect on the state of glycaemic control, but promotes to reduce microalbuminuria. Some publications reported worsening of glycaemic control by treatment with omega-3 PUFAs in patients with T2DM. In particular the results of 6 -weeks, double-blind study of the effect $4 \mathrm{~g}$ $\mathrm{EPA}+\mathrm{DHA} /$ day (compared with the same dose 
of olive oil) in 59 patients with T2DM with essential hypertension showed increase of preprandial glucose level, but no changes of glycated hemoglobin $\mathrm{A}_{1 \mathrm{c}}\left(\mathrm{HbA}_{1 \mathrm{c}}\right)$, preprandial insulin and C-peptide concentrations [9]. Prescription of $1.7 \mathrm{~g}$ of EPA and DHA/day to 935 patients with hypertriglyceridaemia and other risk factors of CVD during the year was accompanied by a negative impact on glucose metabolism parameters [11].

A meta-analysis of 18 studies found a significant effect of fish oil to lower TG concentrations and increase high-density lipoprotein cholesterol (HDL-C) in the blood; while there were no statistically significant changes in preprandial glucose, $\mathrm{HbA}_{1 c}$, total cholesterol (total C), low density-lipoprotein cholesterol (LDL-C) levels [11]. Increased consumption and/or inclusion to treatment omega-3 PUFAs drugs could improve insulin sensitivity and glucose homeostasis; prevent changes and further development of T2DM, which is largely mediated by inhibition of the free fatty acids accumulation in the muscles and liver. These effects are probably mediated by transcription factors activity, that are related with genes expression involved in the synthesis and oxidation of lipids. So, omega-3 PUFAs may affect the IR and glucose homeostasis by inhibition of IR in the muscle tissue $>$ adipose tissue $>>$ liver, inhibition of insulin secretion, which defer the development of T2DM; and on the state of lipid metabolism (in particular, reduce the concentration of TG, very low density-lipoprotein cholesterol (VLDL-C), increase of HDL-C, improve lipid profile by mixed dyslipoproteinemia (DLP) [27].

\section{Omega-3 polyunsaturated fatty acids and lipid metabolism}

Omega-3 PUFAs decrease VLDL assembly and secretion, resulting in diminished triacylglycerol production, through a decreased sterol receptor element binding protein-1c activity. Pharmacokinetic data obtained from obese male subjects with DLP show that $4 \mathrm{~g}$ of fish oil per day decrease the production of VLDL apolipoprotein B (ApoB), without a change in the pool size of LDL-ApoB, and also with no change in the fractional catabolic rate of VLDL ApoB [13, 28]. In addition, omega-3 PUFAs increase beta-oxidation of other fatty acids in mi- tochondria and peroxisomes, possibly through activation of peroxisome proliferator-activated receptor-alpha (PPAR-alpha). This occurs despite the evidence that omega-3 PUFAs are weak PPAR agonists [13, 29, 30].

The highly concentrated pharmaceutical preparation Omacor ${ }^{\mathrm{TM}}$ (Pronova Biocare, Lysaker, Norway), known as Lovaza ${ }^{\mathrm{TM}}$ (GlaxoSmithKline, St Petersberg, FL, USA) in North America is approved by the FDA as an adjunct to diet to reduce very high TG levels $\left(\geq 5.65 \mathrm{mmol} \cdot \mathrm{L}^{-1}\right.$ or $\left.\geq 500 \mathrm{mg} \cdot \mathrm{dL}^{-1}\right)$ in adults. Each 1-g capsule of omega-3-acid ethyl esters contains ethyl esters of EPA (0.465 g) and DHA $(0.375 \mathrm{~g})$. Patients take a once-daily dose of $4 \mathrm{~g}$ or two 2-g doses (two capsules twice daily). Clinical trials have shown that administration of $4 \mathrm{~g} \cdot$ day $^{-1}$ of Lovaza ${ }^{\mathrm{TM}}$ results in a decrease in TG levels of $30-50 \%[13,31,32]$. In addition, administration of Lovaza ${ }^{\mathrm{TM}}$ does not affect the efficacy of statins. In patients with combined hyperlipidaemia, co-administration of Lovaza ${ }^{\mathrm{TM}}$ with statins was a safe and effective means of lowering serum TG, despite the persistent high TG levels when the patients received statins alone [13, 33].

The COMBOs study evaluated the effects of adding omega-3-acid ethyl esters to stable simvastatin (e.g., Zocor ${ }^{\mathrm{TM}}$ ) therapy $(40 \mathrm{mg} /$ day) in patients with persistent hypertriglyceridaemia (at or above $200 \mathrm{mg} / \mathrm{dL}$ and less than $500 \mathrm{mg} / \mathrm{dL}$ ) [34, 35]. After an 8-week lead-in phase with simvastatin, patients received omega-3-acid ethyl esters or placebo for an additional 8 weeks. The reduction from baseline in non-HDL-C (the primary outcome variable) was significantly greater with omega-3-acid ethyl esters plus simvastatin than with simvastatin alone $(-9.0 \%$ vs. $-2.2 \%$, respectively; $P<0.001)$. Treatment with omega- 3 -acid ethyl esters also significantly reduced TG levels $(-29.5 \%$ vs. $-6.3 \%)$ and VLDL-C levels $(-27.5 \%$ vs. $-7.2 \%)$ and significantly increased HDL-C levels compared with placebo (3.4\% vs. $-1.2 \%$ ) (all comparisons, $P<0.05$ ) [35, 36].

Omega-3 PUFAs prescription to 223 patient with CHD and DLP (6 g/day for 3 months and then $3 \mathrm{~g} /$ day for $21 \mathrm{month}$ ) has been associated with improved clinical course of the disease, that allowed to suggest their potentially antiatherosclerotic properties [37]. 
However, effects of omega-3 PUFAs on the development/progression of CVD and mortality in patients with DM are not fully understood. The question of the feasibility and additional benefits of omega-3 PUFAs administration in combination with statins to avoid polypragmasia in the treatment of diabetic vascular disorders is open $[11,13]$.

To explore the effectiveness of some abovementioned compounds, we examined 36 patients with T2DM and definite CAN. The study was conducted as part of the research work of the Department of Endocrinology of Danylo Halytsky Lviv National Medical University «Specifics of metabolic, functional, and structural disorders of the cardiovascular system and digestive organs in patients with diabetes mellitus» (State Registration Number 0111U000131).

Patients were aged between 50-59 years with disease duration 1-6 years and median $\mathrm{HbA}_{1 \mathrm{c}} 7.1 \pm 0.12 \%$. CAN was diagnosed according to previously proposed criteria $[38,39]$. The work was done according to the principles of the Declaration of Helsinki, and all subjects signed an informed consent prior their inclusion in the study.

Patients were allocated to next treatment groups: the first group received traditional antihyperglycemic therapy ( $n=15$, control group); patients in group $2(n=21)$, received in addition to standard treatment 1 capsule/day of the omega-3 PUFAs (Omacor ${ }^{\mathrm{TM}}$ ). The duration of the treatment was three months.

The concentration of glucose in the blood was determined by the glucose oxidase method, while $\mathrm{HbA}_{1 \mathrm{c}}$ was assessed by using an extremely sensitive method of ion-exchange liquid chromatography with D-10 analyzer and BIO-RAD reagents (USA). Determination of immunoreactive insulin (IRI) was performed using commercial kits from immunogen insulin immunoradiometric assay reagents (Czech Republic). Lipid metabolism was assessed by the concentration of TC, LDL-, HDL-, VLD-L cholesterol measurements.

Immunoreactive insulin, insulin resistance

Table 1 and lipid metabolism parameters after 3 -mo of omega-3
polyunsaturated fatty acids therapy

\begin{tabular}{c|c|c|c|c}
\hline \multirow{2}{*}{ Parameter } & \multicolumn{4}{|c}{ Patients with T2DM and definite CAN } \\
& Groups & Baseline & $\begin{array}{c}\text { After } \\
\text { treatment }\end{array}$ & $\begin{array}{c}\text { \% change } \\
\text { from baseline }\end{array}$ \\
\cline { 2 - 5 } & Control group & $27.79 \pm 2.13$ & $26.01 \pm 2.25$ & $-6.8 \pm 2.0$ \\
\hline \multirow{2}{*}{ IRI (mcIU/ml) } & Treatment group & $25.83 \pm 2.57$ & $23.17 \pm 2.3$ & $-10.3 \pm 1.1$ \\
\cline { 2 - 5 } & Control group & $9.04 \pm 0.99$ & $8.38 \pm 0.9$ & $-7.17 \pm 1.81$ \\
\cline { 2 - 5 } HOMA-IR & Treatment group & $8.22 \pm 1.03$ & $7.21 \pm 0.87$ & $-10.51 \pm 1.79$ \\
\hline \multirow{2}{*}{ LDL-C (mmol/l) } & Control group & $4.59 \pm 0.16$ & $4.25 \pm 0.17$ & $-8.3 \pm 1.4$ \\
\cline { 2 - 5 } & Treatment group & $4.15 \pm 0.17$ & $3.68 \pm 0.22$ & $-12.8 \pm 1.9$ \\
\hline \multirow{2}{*}{ HDL-C (mmol/l) } & Control group & $0.84 \pm 0.03$ & $0.87 \pm 0.03$ & $4.1 \pm 1.0$ \\
\cline { 2 - 5 } & Treatment group & $0.78 \pm 0.03$ & $0.88 \pm 0.04 \mathrm{a}$ & $7.1 \pm 0.54$ \\
\hline \multirow{2}{*}{ TG (mmol/l) } & Control group & $2.52 \pm 0.12$ & $2.31 \pm 0.11$ & $-8.3 \pm 1.2$ \\
\cline { 2 - 5 } & Treatment group & $2.55 \pm 0.14$ & $1.61 \pm 0.08 \mathrm{c}$ & $-35.4 \pm 2.6$ \\
\hline \multirow{2}{*}{ Total C (mmol/l) } & Control group & $6.59 \pm 0.18$ & $6.13 \pm 0.15$ & $-6.7 \pm 1.1$ \\
\cline { 2 - 5 } & Treatment group & $6.07 \pm 0.18$ & $5.59 \pm 0.2$ & $-8.2 \pm 1.1$ \\
\hline
\end{tabular}

The results are presented as absolute values and $\%$ change from baseline, ( $\%$, Mean $\pm S E M)$; $a P<0.05, c P<0.001$, compared to baseline. T2DM: Type 2 diabetes mellitus; CAN: Cardiovascular autonomic neuropathy; Omega-3 PUFAs: Omega-3 polyunsaturated fatty acids; IRI: Immunoreactive insulin; HOMA-IR: Insulin resistance homeostatic model assessment; LDL cholesterol: Low-density lipoprotein cholesterol; HDL cholesterol: High-density lipoprotein cholesterol; TG: Triglycerides; Total C: Total cholesterol. 
The lipid fractions were determined by using HUMAN reagents (Germany) for the analyzer HUMANLAYZER 2000. HOMA-IR [Homeostasis Model Assessment (HOMA) HOMA-IR] was calculated according to the formula: fasting IRI $(\mathrm{mcIU} / \mathrm{ml}) \mathrm{x}$ fasting glucose $(\mathrm{mmol} / \mathrm{L}) / 22.5$ [40]. Statistics-ANOVA.

Changes of IRI, HOMA-IR, and lipid metabolism parameters among patients with T2DM and definite CAN after 3-mo of omegaPUFAs therapy are given in Table 1.

We found out that the $\mathrm{HbA}_{1 \mathrm{c}}$ of patients with T2DM and definite CAN was not statistically significantly influenced by the treatment $(P>0.05)$. Treatment with the omega-3 PUFAs among patients with T2DM and definite CAN (group 2) lead to a significant increase of the HDL-C level $[7.1 \% \pm 0.54 \%,(P<0.05)]$ and reduction of TG $[-35.4 \% \pm 2.6 \%,(P<0.001)]$. Obtained results of this study could prove that prescription of omega-3 PUFAs is accompanied by a more significant decrease of TG and increase of HDL-C levels compared to patients in control group. Obtained results of this study could prove that prescription of omega-3 PUFAs is accompanied by hypolipidaemic effect without influence on glucose metabolism.

\section{Omega-3 polyunsaturated fatty acids and inflammation}

Eicosanoids include prostaglandins, thromboxanes and leukotrienes that are key mediators of inflammatory responses. Arachidonic acid is the substrate for production of series 2 -prostaglandins and thromboxanes and series 4-leukotrienes. When AA is substituted by omega-3 PUFAs-mainly EPA, the resulting eicosanoids are series 3-prostaglandins and thromboxanes and series 5-leukotrienes. EPA actually can, in contrast to DHA, function as a substrate for COX-1 and 5-LOX [13, 41]. Due to the smaller size of the substrate binding site of COX-1 compared with COX-2, the 22 -carbon DHA can however be metabolized by COX-2 [13, 42, 43]. The products of omega-3 PUFAs may be beneficial as they do not induce the same level of inflammation as those derived from arachidonic acid. In humans, supplementation with fish oil has resulted in decreased production of prostaglandin $\mathrm{E}_{2}\left(\mathrm{PGE}_{2}\right), \mathrm{TXB}_{2}$, leukotriene $\mathrm{B} 4\left(\mathrm{LTB}_{4}\right)$, 5-hydroxyeicosatetrae- noic acid and $\mathrm{LTE}_{4}$ by inflammatory cells $e x$ vivo [13, 41, 44].

However, the beneficial effects of omega-3 PUFAs may not exclusively be mediated through eicosanoids production. For example, DHA exerts greater anti-inflammatory effects than EPA in the vascular endothelium. Being the direct precursor of eicosanoids EPA would be expected to have greater effects than DHA if eicosanoids played an important role. Also, these anti-inflammatory effects of fish oils are not altered by a COX blocker, eliminating an exclusive role of for example prostaglandins [13, 45].

Several studies providing fish oil supplements to healthy human volunteers have reported decreased production of tumor necrosis factor (TNF) -alpha, interleukin (IL) -1 beta and IL- 6 by endotoxin-stimulated monocytes or mononuclear cells although not all studies confirm this effect. Some of the studies that fail to show an effect of marine omega-3 PUFAs on cytokine production have provided $<2 \mathrm{~g}$ EPA + DHA day ${ }^{-1}$, which may be an insufficient dose. In cell cultures both EPA and DHA inhibit T cell proliferation and the production of IL-2. Some studies have shown that increased intake of marine omega-3 PUFAs decreases human $\mathrm{T}$ cell proliferation and IL-2 production [41, 44, 46].

To summary, the anti-inflammatory actions of marine omega-3 PUFAs are: reduced leucocyte chemotaxis (via decreased production of some chemo-attractants (e. g. LTB 4 ); down-regulated expression of receptors for chemo-atttactants); reduced adhesion molecule expression and decreased leucocyte-endothelium interaction (via down-regulated expression of adhesion molecule genes (via nuclear factor kappa-lightchain-enhancer of activated B cells (NF-kB), NR1C3 (i.e. PPAR-gamma) etc.); decreased production of eicosanoids from AA (via lowered membrane content of AA; inhibition of AA metabolism); decreased production of AA containing endocannabinoids (via lowered membrane content of AA); increased production of 'weak' eicosanoids from EPA (via increased membrane content of EPA); increased production of anti-inflammatory EPA and DHA containing endocannabinoids (via increased membrane content of EPA and DHA); increased production of pro-resolution resolvins and protectins (via increased membrane content of EPA and 
DHA); decreased production of inflammatory cytokines (via down-regulated expression of inflammatory cytokine genes (via NF-kB, NR1C3 (i. e. PPAR-gamma) etc.); decreased T cell reactivity (via disruption of membrane rafts (via increased content of EPA and DHA in specific membrane regions).

\section{Omega-3 polyunsaturated fatty acids, platelets and haemostatic function}

Omega-3 PUFAs may decrease the risk of atherothrombosis by affecting platelet aggregation and haemostasis. The antithrombotic properties of EPA and DHA have been attributed to the incorporation into platelet phospholipids at the expense of the omega- 6 PUFAs, such as arachidonic acid. An important set of pathways clearly influenced by changes in the omega-3/ omega- 6 ratio are those for synthesis of eicosanoids. These include the COX, LOX and P450 epoxygenase pathways, for which EPA and DHA compete with AA as a substrate, inhibiting the production of the proaggregatory $\mathrm{TXA}_{2}$ originating from arachidonic acid. Indeed, the production of $\mathrm{TXA}_{2}$ from platelets stimulated by a variety of agonists decreased by between $60 \%$ and $80 \%$ after fatty acid supplementation both in vitro and in vivo [13, 47]. Incorporation of DHA into human platelets produced greater inhibition of platelet aggregation than either EPA alone or a combination of EPA and DHA. Docosahexaenoic acid was also more potent than EPA in inhibiting platelet $\mathrm{TXA}_{2}$ synthesis. In addition DHA, and to some extent EPA, act as antagonists of the $\mathrm{TXA}_{2} / \mathrm{PGH}_{2}$ receptor in human platelets, thereby blocking the activation of platelets through the AA pathway $[13,47]$.

Omega-3 PUFAs can modulate the nitroso-redox balance by increasing vasculoprotective nitric oxide (NO) and decreasing $\mathrm{O}_{2}^{-}$production in endothelial cells. This finding may be extremely valuable for diabetic patients whose disease manifests as a high oxidative status. Furthermore, fish oil-derived omega-3 PUFAs may also offer several other advantages. Importantly, they are easily absorbed and retained within cellular membranes, where they can act as a readily available supply of free radical-modifying agents. This bioavailability, coupled with their ability to specifically modulates the function of enzymes producing reactive oxygen species and reactive nitrogen species, such as NAD (P) $\mathrm{H}$ and nitric oxide synthase (NOS), suggests that, far from simply being free radical scavengers like other antioxidants, omega-3 PUFAs may be therapeutically superior [49, 50].

Platelets contain all the components of a functioning NO-producing pathway, including the enzyme necessary for the production of the cofactor tetrahydrobiopterin, and are therefore capable of producing NO in response to platelet-specific agonists. In addition, they also contain all the subunits required for the assembly of the NAD (P) H oxidase system. Platelets thus represent an accessible cellular model for functional studies to explore free radical activity in relation to changes in NAD (P) $\mathrm{H}$ oxidase and NOS activity [50, 51].

Fish oil treatment significantly decreased isoprostane levels in the hypertensive T2DM patients, suggesting that omega-3 PUFAs offer an additional therapeutic benefit [50, 52]. These results are in agreement with those of Mori et al. (2003), who demonstrated an omega-3 PUFAs-mediated decrease in isoprostane levels in T2DM patients [53].

Prescription to patients with T2DM $900 \mathrm{mg}$ EPA/day for 8 weeks was accompanied by the inhibition of the platelet activating factor synthesis (in the background of unchanged collagen or ADP-induced platelet aggregation). These effects have been amplified by using EPA $1800 \mathrm{mg} /$ day [37]. The addition of $1800 \mathrm{mg}$ $\mathrm{EPA} /$ day or $3.4 \mathrm{~g} \mathrm{EPA}+\mathrm{DHA}$ to the treatment of patients with $\mathrm{CHD}$ was accompanied with increased fibrinolytic activity. Daily administration of $3.4 \mathrm{~g}$ of EPA and DHA to 40 patients after MI for 4 weeks contributed to the lengthening of bleeding time, but had no effect on other parameters of haemostasis. The results of similar randomized trial of $0.85 \mathrm{~g}$ of EPA and DHA/day prescription to 77 patients in postMI period for 3 month demonstrated the increase in von Willebrand factor activity, and at the same time does not affect the concentration of fibrinogen [13, 54]. Prescription to patients with T2DM $900 \mathrm{mg}$ EPA/day for 8 weeks was accompanied by the inhibition of the platelet activating factor synthesis and this effect was prolonged by the dose increase to $1800 \mathrm{mg} /$ day. 
The results of randomized, double-blind, placebo-controlled trial of fish oil (4 $\mathrm{g}$ of EPA or 4 g DHA/day) and olive oil prescription to 59 patients with T2DM and arterial hypertension for 6 week demonstrate that EPA and $D H A$ lowered sensitivity to collagen and $\mathrm{TXA}_{2}$ formation, but had no effect on other fibrinolytic and endothelial parameters [13]. Consequently, the prescription of EPA and DHA to patients with CHD in post-MI period and to patients with T2DM reduces the platelet aggregation parameters, shows the insignificant anticoagulant effect, is associated with prolongation of bleeding time, moreover DHA has a much more prominent inhibitory effect on platelet aggregation than EPA. It was found that the fish oil (1 g/day) consumption of healthy volunteers for 3 weeks caused significant changes in proteins 65 (proteins necessary to maintain the physiological structure of platelets, ensuring processes of inflammation and thrombosis), without affecting the state of platelets aggregation [13]. Thus, changes in the functional state of platelets actually occur at lower concentrations of omega-3 PUFAs.

\section{Omega-3 polyunsaturated fatty acids and endothelial function}

Classically the term "endothelial dysfunction» strictly refers to reduced endothelium-dependent vasodilation, which is notably associated with impaired bioavailability of the main endothelium-derived relaxing factor, nitric oxide. In addition to promoting vasodilation, NO is a powerful antiatherosclerotic agent, since it reduces leukocyte adhesion, platelet aggregation, and smooth muscle cell proliferation. In the endothelium NO is produced by the eNOS. Reduced NO bioavailability can be the result of either decreased production or increased usage. Several mechanisms, including downregulation of eNOS expression, posttranslational modifications of eNOS, inhibition of the enzyme catalytic activity, enzyme uncoupling, and circulating eNOS inhibitors result in decreased NO release and endothelial dysfunction [55].

In addition to increasing NO production, omega-3 PUFAs decrease oxidative stress. This effect is controversial, since the prooxidant activity of long-chain omega-3 PUFAs especially at high doses has long been debated. However experimental studies conducted so far in cell culture or in vascular beds of experimental animals have shown that relatively large doses of omega-3 PUFAs improve endothelial function by attenuating ROS production as a result of a direct modulatory effect on the sources of ROS formation, including the enzymes NAD (P) $\mathrm{H}$ oxidase and iNOS, finally resulting in reduced peroxynitrite formation. In retinal endothelial cells in culture exposed to high glucose alpha-LA directly reduces ROS information and increased superoxide dismutase activity. A potentiation of endogenous antioxidant enzyme concentrations in plasma as a direct effect of omega-3 PUFAs oral administration has also been reported also by other reports [56].

\section{Omega-3 polyunsaturated fatty acids and blood pressure}

Omega-3 PUFAs intake has shown to reduce BP especially in hypertensive patients by interacting with several mechanisms of blood pressure regulation: reduction of stroke volume and heart rate (HR); improvement of left ventricular $(L V)$ diastolic filling; reduction of peripheral vascular resistances; improvement of endothelial-dependent and endothelial-independent vasodilation (stimulation of NO production; reduction of the asymmetric di-methyl-arginine; reduction of endothelin-1; relaxation of vascular smooth muscle cells; metabolic effects on perivascular adipocytes; endothelial regeneration. Mechanisms of hypertension-related organ damage protection: anti-inflammatory, antioxidant, and antithrombotic effects; reduction of arterial stiffness; experimental effects on LV hypertrophy and abnormal gene expression; effects on atherosclerotic plaque progression and stability [57].

\section{Omega-3 polyunsaturated fatty acids and arterial stiffness}

Arterial stiffening is caused by the loss of vascular elasticity due to factors such as aging and atherosclerosis. It depends from the structural properties of the arterial wall that affect the manner in which pressure, blood flow, and arterial diameter change within each heartbeat. An increased arterial stiffness is associated with hypertension and it is an independent direct predictor of cardiovascular events. The 
measurement of velocity of the pulse-wave velocity (PWV) between two vascular points is an accepted method to assess arterial stiffness [57].

The reasons for improvement of arterial stiffness with the use of omega-3 PUFAs can be related to the hypotensive, anti-inflammatory, and antioxidative effects of these fatty acids, as well as to their ability to improve endothelial cell function. Additional evidence of the beneficial effect of omega-3 PUFAs on the vascular structure comes from the inverse association between omega-3 PUFAs intake and the crosssectional diameter of arteries [57, 58].

The long-chain omega-3 PUFAs offer a scientifically supported means of reducing arterial stiffness and this may account for some of the purported cardioprotective effects of omega-3 PUFAs. As increased arterial stiffness is a risk factor for CVD, omega-3 PUFAs supplementation may provide a means of reducing the risk of CVD and end-organ damage. Accepting that carotid-femoral PWV is a strong predictor of future cardiovascular events, exploring the effects of omega-3 PUFAs on this 'gold standard' measure constitutes an important area for future research. Meta-analysis of randomized and controlled human clinical trials provides compelling evidence that supplementation with long-chain omega-3 PUFAs offers a scientifically supported means of reducing arterial stiffness. It was found that omega-3 PUFAs were effective in independently improving both PWV and arterial compliance with small-tomoderate clinical effects. There was no statistical evidence of heterogeneity or publication bias, thus confidence can be extended to these results [59].

\section{Omega-3 polyunsaturated fatty acids and heart rate variability}

The incorporation of omega-3 PUFAs in synaptic membranes could potentially influence the autonomic control of the heart. The progressive maturation of the autonomic nervous system during fetal and early life renders this period a sensitive time, during which supplementation with omega-3 PUFAs might exert long-term effects on vagal tone and hence heart rate variability (HRV) [60].

Patients with IHD are at higher risk of SCD, and often have depressed HRV. The as- sociation between fish consumption, the content of omega-3 PUFAs in cell membranes and HRV was evaluated in 52 patients with a previous $\mathrm{MI}$ and a decreased $\mathrm{LV}$ ejection fraction $(\leq 40 \%)$. Subjects who consumed fish at least once a week had a slightly (non-significant) higher the standard deviation of $\mathrm{NN}$ intervals (SDNN) compared to those never eating fish. Ischemic heart disease is the predominant underlying disease behind SCD. HRV was measured in 291 patients referred for coronary angiography due to suspected IHD and these measures were related to cell membrane and adipose tissue levels of omega-3 PUFAs. Significant positive correlations were found between time domain HRV indices and levels of omega-3 PUFAs, especially DHA. These associations remained significant also after controlling for several possible confounders. The Framingham study was the first epidemiological report demonstrating a two to fourfold increased risk of IHD and acute MI in diabetic patients. These patients also have an excess of post-MI mortality. Autonomic neuropathy involving the heart may be of importance and CAN carries an excess risk of mortality in patients with DM, including a high risk of SCD. HRV analysis is a well-established tool in the early detection of CAN in patients with DM [61].

Both nervous tissue and heart tissue have a high content of omega-3 PUFAs (especially DHA) and this may be consistent with the finding that this marine omega-3 PUFAs may modulate cardiac autonomic function as assessed by HRV. Thus, omega-3 PUFAs may modulate HRV both at the level of the autonomic nervous system and the heart [61].

\section{Omega-3 polyunsaturated fatty acids and arrhythmias}

Numerous studies report salutary effects of omega-3 PUFAs, i. e. EPA and DHA on CVD risk factors. These effects include lowering of serum TG by reducing of hepatic TG production; lowering of BP by improving of endothelial cell function; decreasing of platelet aggregation by reducing of prothrombotic prostanoids; decreasing inflammation via reduction in 4 -series LT production; protection from arrhythmias by modulation of electrophysiological properties of cardiomyocytes. Systematic meta-analysis 
suggests that high doses of omega-3 PUFAs ( $\sim 3 \mathrm{~g} /$ day) produce a small, but significant decrease in systolic BP in older and hypertensive subjects [5, 6].

Findings show that omega-3 PUFAs intake normalizes myocardial connexin (Cx) 43 mRNA levels in old rats, and $\mathrm{Cx} 43$ protein expression as well as its functional phosphorylated status in both, young and old hypertensive animals. Enhanced Cx43 phosphorylation may in part be attributed to protein kinase $\mathrm{C}$ epsilon type (PKC-ع) that is up-regulated by omega-3 PUFAs. The treatment significantly eliminates abnormal $\mathrm{Cx} 43$ distribution, diminishes the internalization of gap junctions and improves integrity of mitochondria in cardiomyocytes of hypertensive rats. These findings clearly indicate that modulation of $\mathrm{Cx} 43$ channels function and myocardial cell-to-cell coupling by omega-3 PUFAs might be possible $[6,62]$.
The antiarrhythmic effects of omega-3 PUFAs, which occur by blocking various ion channels, are encouraging. In fact, the results of several trials have suggested that dietary supplementation with omega-3 PUFAs might be an effective optional therapy for arrhythmias. However, the FORWARD trial, a prospective, randomized, clinical trial, found that treatment with omega-3 PUFAs over a 6-month period did not reduce recurrent symptomatic atrial fibrillation [63-65]. In the specific study population with paroxysmal atrial fibrillation, it was concluded that omega-3 PUFAs are not a useful treatment. These results do not exclude the potential anti-arrhythmic effects of prescription omega-3 PUFAs in combination with anti-arrhythmic drugs in different populations, such as patients with heart failure; however, validation in prospective trials is required [65].

\section{CONCLUSION}

Diabetes mellitus is a global epidemic affecting at least $8.3 \%$ of the population and 371 million people worldwide with a significant proportion $(50 \%)$ remaining undiagnosed. It is estimated that almost one of six people are currently at risk of developing diabetes-related complications. The majority of patients with long-term course of diabetes mellitus [mainly type 2 diabetes mellitus] are diagnosed with coronary heart disease due to coronary artery atherosclerosis.

Numerous studies report salutary effects of omega-3 polyunsaturated fatty acids, i.e. eicosapentaenoic and docosahexaenoic acid on cardiovascular diseases risk factors. These effects include lowering of serum triglyceride by reducing of hepatic TG production; lowering of blood pressure by improving of endothelial cell functution; decreasing of platelet aggregation by reducing of prothrombotic prostanoids; decreasing inflammation via reduction in 4-series leukotrienes production; protection from arrhythmias by modulation of electrophysiological properties of cardiac myocytes and normalization of sympathic-vagal interaction; moderate hypotensive effect. Results of our study prove that prescription of omega-3 polyunsaturated fatty acids is accompanied by hypolipidaemic effect without influence on glucose metabolism. These aspects justify the benefits and feasibility of using this drug under conditions of diabetes mellitus development. However, further randomized, double-blind, placebo-controlled trials of larger scale, longer duration and follow-up period with better-designed protocol and appropriate selection of study population may clearly demonstrate the pharmacological effect of omega-3 PUFAs on investigated parameters.

\section{REFERENCES}

1. American Diabetes Association. Diabetes Care 2016; 39 (1): S1-2.

2. International Diabetes Federation. IDF Diabetes Atlas, 7 ed. 2015.

3. Marazzi G, Volterrani M, Rosano GM. Int J Cardiol 2008; 127 (1): 124-125. doi: 10.4239/wjd.v6.i2.245.

4. Rutter MK, Nesto RW. Eur Heart J 2011; 32 (18): $2247-$ 2255. doi: 10.1093/eurheartj/ehr154.
5. Bonafini S, Antoniazzi F, Maffeis C, et al. Prostaglandins Other Lipid Mediat 2015; 120 (7): 72-79. doi: 10.1016/j.prostaglandins.2015.03.006.

6. Egan BT, Szeiffova BB, Viczenczova C, et al. Physiol Res 2016; 65 (1): 29-42.

7. Harris WS. Pharmacol Res 2007; 55 (3): 217-223.

8. Harris WS, von Schacky C. Prev Med 2004; 39 (1): 212 220. 
9. von Schacky C. Curr Opin Clin Nutr Metab Care 2008; 11 (2): 94-99.

10. Dhule SS, Gawali SR. Natl J Physiol Pharm Pharmacol 2014; 4 (2): 121-123.

11. Kandasamy N, Joseph F, Goenka N. Br J Diabet Vasc Dis 2008; 8 (3): 121-128.

12. Widmer RJ, Flammer AJ, Lilach O. et al. Am J Med 2015; 128 (3): 229-238. doi: 10.1016/j.amjmed. 2014.10.014.

13. de Roos B, Mavrommatis Y, Brouwer IA. Br. J. Pharmacol 2009;158(2): 413-428. doi: 10.1111/j.1476-5381.2009. 00189.x.

14. Ebbesson SOE, Devereux RB, Cole S. et al. Am Heart $J$ 2010; 159 (6): 1020-1025. doi: 10.1016/j.ahj.2010.03.001.

15. Bang HO, Dyerberg J. Dan Med Bull 1980; 27 (4): 202-205.

16. Ebbesson SOE, Tejero ME, Nobmann ED, et al. J Cardiometab Syndr 2007; 2 (4): 244-249.

17. ORIGIN Trial Investigators, Bosch J, Gerstein HC, et al. $N$ Engl J Med 2012; 367 (4): 309-318. doi: 10.1056/ NEJMoa1203859.

18. Lemaitre RN, King IB, Mozaffarian D, et al. Am J Clin Nutr 2003; 77 (2): 319-325.

19. Mozaffarian D, Lemaitre RN, Kuller LH, et al. Circulation 2003; 107 (10): 1372-1377.

20. Mozaffarian D, Geelen A, Brouwer IA, et al. Circulation 2005; 112 (13): 1945-1952.

21. Burr ML, Fehily AM, Gilbert JF, et al. Lancet 1989; 2 (8666): 757-761.

22. Burr ML, Dunstan FD, George CH. J Membr Biol 2005; 206 (2): 155-163.

23. Yokoyama M, Origasa H, Matsuzaki M, et al. Lancet 2007; 369 (9567): 1090-1098.

24. Geleijnse JM, Giltay EJ, Schouten EG, et al. Am Heart J 2010; 159 (4): 539-546. doi: 10.1016/j.ahj.2009.12.033.

25. Kromhout D, Giltay EJ, Geleijnse JM. N Engl J Med 2010; 363 (21): 2015-2026. doi: 10.1056/NEJMoa1003603.

26. Rauch B, Schiele R, Schneider S, et al. Circulation 2010; 122 (21): 2152-2159. doi: 10.1161/CIRCULATIONAHA. 110.948562 .

27. Carpentier YA., Portois L, Malaisse JW. Am J Clin Nutr 2006; 83: 1499-1504.

28. Chan DC, Watts GF, Barrett PH, et al. Diabetes 2002; 51 (8): 2377-2386.

29. Davidson MH. Am J Cardiol 2006;98(4A): 27-33.

30. Jump DB. Curr Opin Lipidol 2008; 19 (3): 242-247.

31. Harris WS. Am J Clin Nutr 1997; 65 (5): 1645S-1654S.

32. Stalenhoef AF, de Graaf J, Wittekoek ME, et al. Atherosclerosis 2000; 153 (1): 129-138.

33. McKenney JM, Swearingen D, Di Spirito M, et al. $J$ Clin Pharmacol 2006; 46 (7): 785-791.
34. Davidson MH, Stein EA, Bays HE, et al. Clin Ther 2007; 29 (7): 1354-1367.

35. Bradberry JC, Daniel E, Hilleman DE. P T J 2013; 38 (11): 681-691.

36. Lovaza prescribing information. Research Triangle Park, North Carolina, 2014.

37. von Schacky C. Cell Mol Biol 2010; 56 (1): 90-98. doi: 10.3390/nu2030375.

38. Spallone V, Ziegler D, Freeman R, et al. Diabetes Metab Res Rev 2011; 27 (7): 639-653. doi: 10.1002/dmrr.1239.

39. Tesfaye S, Boulton AJ, Dyck PJ, et al. Diabetes Care 2010; 33 (12): 2285-2293. doi: 10.2337/dc10-1303.

40. Matthews DR, Hosker JP, Rudenski AS, et al. Diabetologia 1985; 28 (7): 412-419.

41. Lee TH, Hoover RL, Williams JD, et al. $N$ Engl J Med 1985; 312 (19): 1217-1224.

42. Massaro M, Habib A, Lubrano L, et al. Proc Natl Acad Sci USA 2006; 103 (41): 15184-15189.

43. Serhan CN, Chiang N, Van Dyke TE. Nat Rev Immunol 2008; 8 (5): 349-361. doi: 10.1038/nri2294.

44. Trebble T, Arden NK, Stroud MA, et al. Br J Nutr 2003; 90 (2): 405-412.

45. De Caterina R, Liao JK, Libby P. Am J Clin Nutr 2000; 71 (1): S213-223.

46. Calder PC. Am J Clin Nutr 2006; 83 (6): 1505-1519. doi: 10.1093/ajen/83.6.1505S.

47. Kristensen SD, Schmidt EB, Dyerberg J. J Intern Med 1989; 731: 141-150.

48. Kramer HJ, Stevens J, Grimminger F, et al. Biochem. Pharmacol 1996; 52 (8): 1211-1217.

49. Matesanz N, Park G, McAllister H, et al. Invest Ophthalmol Vis Sci 2010; 51 (12): 6815-6825. doi: 10.1167/ iovs.10-5339

50. McDonald DM, O'Kane F, McConville M, et al. Diabetes Care 2013; 36 (4): 998-1005. doi.org/10.2337/dc12-0304.

51. Dixon LJ, Morgan DR, Hughes SM, et al. Circulation 2003; 107 (13): 1725-1728. doi: 10.1016/j.amjcard.2008. 12.028 .

52. Block RC, Abdolani A, Smith B, et al. Prostaglandins Leukot Essent Fatty Acids 2013; 89 (1): 9-18.

53. Mori TA, Woodman RJ, Burke V, et al. Free Radic. Biol. Med 2003; 35 (7): 772-781.

54. Lee KW, Blann AD, Lip GY. Thromb. Res 2006; 118 (3): 305-312.

55. Tousoulis D, Kampoli A-M, Papageorgiou CTN, et al. Cur Vasc Pharmacol 2012; 10 (1): 4-18. doi: 10.2174/157016 112798829760 .

56. Zhang W, Fu F, Tie R, et al. Vasa 2013; 42 (6): 421-428. doi: 10.1024/0301-1526/a000311. 
57. Colussi G, Catena C, Novello M, et al. available at: http://dx.doi.org/10.5772/63501.

58. Yeboah J, Folsom AR, Burke GL, et al. Circulation 2009; 120 (6): 502-509. doi: 10.1161/CIRCULATIONAHA. 109.864801.

59. Pase MP, Grima NA, Sarris J. Br J Nutr 2011; 106 (7): 974-980. doi: 10.1017/S0007114511002819.

60. Massin M, von Bernuth G. Pediatr Cardiol 1997; 18 (4): 297-302.

61. Maser RE, Lenhard MJ. J Clin Endocrinol Metab 2005; 90 (10): 5896-5903
62. Reiffel JA, Mcdonald A. Am J Cardiol 2006; 98 (4A): 50-60.

63. Macchia A, Grancelli H, Varini S, et al. J Am Coll Cardiol 2013; 61 (4): 463-468. doi: 10.1016/j.jacc.2012.11.021.

64. Mozaffarian D, Wu JH. J Am Coll Cardiol 2011; 58 (20): 2047-2067. doi: 10.1016/j.jacc.2011.06.063.

65. Endo J, Arita M. J Cardiol 2016; 67 (1): 22-27. doi: 10.1016/j.jjcc.2015.08.002.

\author{
ПАТОГЕНЕТИЧНІ МЕХАНІЗМИ ТА ТЕРАПЕВТИЧНІ АСПЕКТИ \\ ЗАСТОСУВАННЯ ОМЕГА-З ПОЛІНЕНАСИЧЕНИХ ЖИРНИХ КИСЛОТ \\ ПРИ ЦУКРОВОМУ ДІАБЕТІ \\ (огляд літератури та результати власних досліджень) \\ Сергієнко В. О., Ажмі С., Сергієнко Л. М., Сергієнко О. О. \\ Львівський національний медичний університет ілені Данила Галицького, \\ м. Львів, Україна \\ serhiyenkoa@gmail.com
}

В огляді висвітлені сучасні уявлення про основні механізми дії омега-3 поліненасичених жирних кислот та результати власних досліджень. Проаналізовано особливості впливу омега-3 поліненасичених жирних кислот на: 1) метаболізм глюкози; 2) хронічний запальний процес; 3) агрегацію тромбоцитів та гемостаз; 4) ендотеліальну дисфункцію; 5) регуляцію артеріального тиску; 6) жорсткість судинної стінки; 7) варіабельність ритму серця; 8) розвиток аритмій. Ми встановили, що омега-3 поліненасичені жирні кислоти сприяють гіполіпідемічному ефекту: зниженню рівня тригліцеридів та підвищенню холестерину ліпопротеїнів високої щільності. Аналіз доказової бази свідчить про зниження кардіо-васкулярного ризику при застосуванні омега-3 поліненасичених жирних кислот та обгрунтовує переваги та доцільність застосування даного препарату при цукровому діабеті.

К л ючов і слов а : омега-3 поліненасичені жирні кислоти, механізм дії, цукровий діабет.

\author{
ПАТОГЕНЕТИЧЕСКИЕ МЕХАНИЗМЫ И ТЕРАПЕВТИЧЕСКИЕ АСПЕКТЫ \\ ПРИМЕНЕНИЯ ОМЕГА-З ПОЛИНЕНАСЫЩЕННЫХ ЖИРНЫХ КИСЛОТ \\ ПРИ САХАРНОМ ДИАБЕТЕ \\ (обзор литературы и результаты собственных исследований) \\ Сергиенко В. А., Ажми С., Сергиенко Л. М., Сергиенко А. А. \\ Львовский национальной медицинский университет илени Данила Галицкого, \\ г. Львов, Украина \\ serhiyenkoa@gmail.com
}

В обзоре освещены современные представления относительно основных механизмов действия омега-3 полиненасыщенных жирних кислот при сахарном диабетом и результаты собственных исследований. Проанализированы особенности влияния омега-3 полиненасыщенных жирных кислот на: 1) метаболизм глюкозы; 2) хронический воспалительный процесс; 3) агрегацию тромбоцитов и гемостаз; 4) эндотелиальную дисфункцию; 5) регуляцию артериального давления; 6) параметры жесткости сосудистой стенки; 7) вариабельность ритма серца; 8) развитие аритмии. Нами установлено, что омега-3 полиненасыщенные жирные кислоти способствуют гиполипидемическому эффекту: снижению уровня триглицеридов, увеличению холестерина липопротеидов високой плотности в крови. Анализ доказательной базы свидетельствует об снижении кардио-васкулярного риска при применении омега-3 полиненасыщенных жирных кислот, обосновывает преимущества и целесобразность применения даного препарата при сахарном диабете.

К л ю че вые с ло в а : омега-3 полиненасыщенные жирные кислоты, механизм действия, сахарный диабет. 


\section{PATHOGENETIC MECHANISMS AND THERAPEUTIC ASPECTS \\ OF OMEGA-3 POLYUNSATURATED FATTY ACIDS \\ IN DIABETES MELLITUS \\ (literature review and own data)}

V. Serhiyenko, S. Azhmi, L. Serhiyenko, A. Serhiyenko

Lviv National Medical University named by Danylo Halitsky, Lviv, Ukraine

serhiyenkoa@gmail.com

In the review the present day data and own results about mechanisms of omega-3 polyunsaturated fatty acids are presented. The peculiarities of influence on 1) glucose metabolism; 2) chronic inflammatory process; 3) platelet aggregation and hemostasis; 4) endothelial dysfunction; 5) blood pressure regulation; 6) parameters of the vascular wall rigidity; 7) heart rate variability; 8) development of arrhythmias are presented. Results of our study prove that its prescription is accompanied by hypolipidaemic effect. Numerous studies report salutary effects of omega-3 polyunsaturated fatty acids on cardiovascular diseases risk factors and justify the benefits of using this drug by diabetes mellitus.

Key words: omega-3 polyunsaturated fatty acids, mechanism of action, diabetes mellitus. 